\title{
Over-Exploitation of Water and Natural Resources in Al-Hira, Libya
}

\author{
Mohamed Ramadhane El Zarroug1 ${ }^{*}$, Issam Daghari², Sami H. Almabrok ${ }^{3}$, Charles Muanda4, \\ Jean Robrt Kompany ${ }^{4}$
}

${ }^{1}$ Tripoli University, Tripoli, Libya

${ }^{2}$ Green-Team Lab, Tunisian National Institute of Agronomy, IRESA, Carthage University, Tunis, Tunisia

${ }^{3}$ Department of Chemistry, Faculty of Science, University of Benghazi, Benghazi, Libya

${ }^{4}$ ISTB, Kinshasa, Democratic Republic of Congo

Email: *Fadelzarroug@yahoo.com

How to cite this paper: El Zarroug, M.R., Daghari, I., Almabrok, S.H., Muanda, C. and Kompany, J.R. (2021) Over-Exploitation of Water and Natural Resources in Al-Hira, Libya. Open Access Library Journal, 8: e7059.

https://doi.org/10.4236/oalib.1107059

Received: June 29, 2021

Accepted: August 17, 2021

Published: August 20, 2021

Copyright $\odot 2021$ by author(s) and Open Access Library Inc.

This work is licensed under the Creative Commons Attribution International License (CC BY 4.0).

http://creativecommons.org/licenses/by/4.0/

(c) (i) Open Access

\begin{abstract}
The problem of water scarcity and salinity in North Africa is one of the main important constraints to any development. Libya is considered a Saharan country more than $90 \%$ of its area. Average annual rain is about $100 \mathrm{~mm}$ while evapotranspiration is more than $2000 \mathrm{~mm}$. The Al-Hira study area belongs to the Al Djfara plain in north-western Libya, which is one of the most important pastoral areas of the region and it was until the 90 s considered a good grazing area. The study area covers an area of approximately 269,938 hectares. The study carried out in the Al Hira area belonging to the Djfara plain showed an advanced state of degradation of natural resources: 1) decrease in irrigated areas and shrub vegetation; 2) increase in bare land areas; 3) fair water management (poor irrigation uniformity, bad irrigation scheduling). The irrigated areas were decreased from 18,000 to 12,000 ha between 1996 and 2008; an increase in bare soil was observed (23,000 ha to about 35,000 ha) between 1988 and 2009. The uniformity of localized irrigation under olive trees is often less than $50 \%$, indicating the need to replace all the irrigation networks. In the case of sprinkler irrigation, irrigation equipment appears to meet the standards but the uniformity coefficient obtained at field level is very low (63\%). The study on natural resources management in this area is imperative. Also an integrated water resources scheme is necessary for a better use of transferred saline water and aquifer fresh water.
\end{abstract}

\section{Subject Areas}

Environmental Sciences

\section{Keywords}

Water Scarcity, Drought, Uniformity of Irrigation 


\section{Introduction}

Desertification has become very influential and affects the whole world (UNEP, 1978) [1]. Overexploitation of natural resources, overgrazing and irresponsible human use have been commonly observed in some areas like our study area (Ben Mahmoud, 1993) [2] in addition to climate change. The water deficit is around $2000 \mathrm{~mm}$ in Libya.

The study area is a semi-dry area with sensitive soil and prevailing climatic conditions makes it a pasture area for long periods (Hamza, 2006) [3]. With the transfer of water by the Libyan artificial river to more than $2000 \mathrm{~km}$; irrigated areas of over 20,000 ha have been created. These irrigated areas can be a development engine in this area, like the oases in the south of Tunisia. The abandonment of irrigated areas has been observed in recent years; testifying to reckless use of water in this area and even salty areas is present.

The objectives of this article were 1) to identify the dimensions of one of the environmental problems of desertification in the El Hira area, 2) to assess the localized and sprinkler irrigation systems used in this area, and 3) assess the spread of salinity, especially since all the irrigated areas are created using transferred water with a salinity greater than $2 \mathrm{~g} / \mathrm{l}$ over a distance greater than 2000 $\mathrm{km}$.

\section{Materials and Methods}

\subsection{Study Area}

Al-Hira is located in the northwest of Libya, (Figure 1) and it's a part of the important Djafara plain, one of the most important pastoral areas, near Al Azizia town with a longitude of $31^{\circ} \mathrm{N}$ and a latitude of 13:01 E. Desert crops were encountered in most areas such as castor crops (Ricinus-Communis), ring crops (Typhaelephanfing), retama, bitter melon (Citrullus-Colocyntis) and prickly pear (Opuntia-Flcus-Indica).

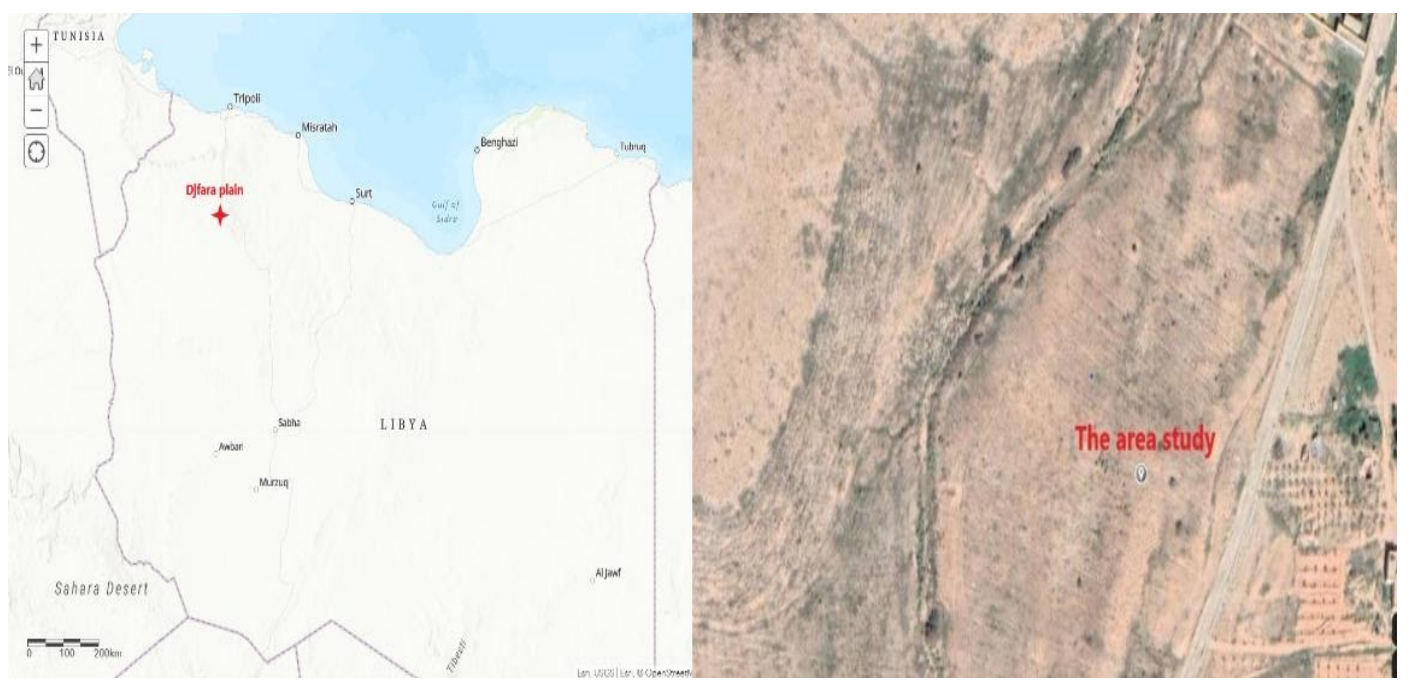

Figure 1. Study area of Al-Hira (Right) located in the Al Djfara plain (Left). 
Rain varied between 200 and $250 \mathrm{~mm}$, a speed wind of $3 \mathrm{~m} / \mathrm{s}$ is almost encountered, relative humidity recorded by the meteorological station was $80 \%$ during January and 30\% during August for the period 1945-2006. The average annual air temperature is $26^{\circ} \mathrm{C}$ (Table 1 ).

The combination of all these factors makes the soil granular and non-contiguous, making its light weight and conducive to wind transport, which leads to desertification of the region; the presence of sand dunes in the region is only a result.

Physical and chemical properties analysis shows that (El Zarroug and al., 2020) [4]:

- The percentage of Calcium Carbonate in the soil of the study area varies between $0.5 \%$ and $14.5 \%$.

- Total dissolved salts shows acceptable values varying between 0.69 and 1.53 $\mathrm{dS} / \mathrm{m}$.

- Average field capacity and wilting point are very low, respectively less than 7 and $4 \%$, which means that there is little capacity of soil moisture retention and gives an indication that the soil is sandy or predominantly sand induced by wind erosion (El Zarroug and al., 2020) [4].

- The percentage of organic matter is very low (about $0.4 \%$ ).

\subsection{Field Experiments and Main Parameters Measured}

\subsubsection{Soil and Water Salinity}

Soil profiles salinity was measured by using the saturated past extract method (USSL, 1954) or the non-destructive method using Geonics EM38 (Aragüés and al., 2010) [5], (Azza and al., 2020) [6] Water electrical conductivity measured by using field conducivimeter.

\subsubsection{Irrigation Assessment}

The main irrigation methods encountered are surface, sprinkler and localized irrigation. Given the development of localized and sprinkler irrigation techniques in recent years presenting the advantage of a reduced need for labor, only these techniques have been evaluated.

1) Case of sprinkler irrigation

This is mainly supplemental irrigation of wheat. The large pivot, big gun are totally damaged and abandoned. The Hand-moved sprinklers used have a range of $16 \mathrm{~m}$

Table 1. Monthly and maximum average temperature of El Azizia meteorological station (1945-2006). (https://public.wmo.int/en, http://www.wunderground.com/blog/weatherhistorian/comment.html?entrynum=2)

\begin{tabular}{cccccccccccccc}
\hline Month & 1 & 2 & 3 & 4 & 5 & 6 & 7 & 8 & 9 & 10 & 11 & 12 & Annual average \\
\hline $\begin{array}{c}\text { Average } \\
\text { temperature }\left({ }^{\circ} \mathrm{C}\right)\end{array}$ & 15 & 16 & 19 & 22 & 27 & 34 & 35 & 35 & 33 & 27 & 22 & 16 & 25.8 \\
$\begin{array}{c}\text { The highest } \\
\text { temperature } \\
\text { measured }\left({ }^{\circ} \mathrm{C}\right)\end{array}$ & 30 & 33 & 44 & 48 & 49 & 52 & 51 & “5 5 ” & 51 & 50 & 43 & 30 & $\begin{array}{c}\text { temperature } \\
\text { temeasured) }\end{array}$ \\
\hline
\end{tabular}


The most common coefficient of uniformity used to evaluate sprinkler irrigation is the Christiansen CU coefficient:

$$
\mathrm{CU}=\left(1-\sum\left|\bar{h}-h_{i}\right| /(n \bar{h})\right) * 100
$$

$h_{i}$ : rainfall collected in the rain gauge $i$.

$\bar{h}$ : average rainfall.

$n$ : number of rain gauges.

A coefficient of uniformity of at least $80 \%$ is required.

To calculate $\mathrm{CU}$, points belonging to the middle of three zones $Z_{4}, Z_{3}$ and $Z_{2}$ (Figure 2). In the case of several sprinklers arranged in a square with a spacing equal to the scope, zone $Z_{4}, Z_{3}$ and $Z_{2}$ are watered respectively by 4,3 and 2 sprinklers.

Irrigation evaluation experiments were conducted in the laboratory and in the field. In the laboratory, an irrigation experiment with a single $16 \mathrm{~m}$ sprinkler of the most common type in the study area was carried out in the laboratory under conditions of total absence of wind at the National Agronomic Institute of Tunisia, the pressure used was $30 \mathrm{~m}$ during the month of March 2018. In the field, the rainfall collected in 9 rain-gauges was measured using the same sprinklers with a range of $16 \mathrm{~m}$ and with a spacing of $16 \mathrm{~m}$ in February 2018.

2) case of localized irrigation

The dripper's discharges are $2 \mathrm{l} / \mathrm{h}$ and $4 \mathrm{l} / \mathrm{h}$ after farmers. For the evaluation of irrigation uniformity, we applied the commonly known procedure which consists in measuring the flow of at least 4 drippers on at least 4 laterals in an irrigation area (CEMAGREF, 1990) [7]. The laterals chosen are in addition to the first

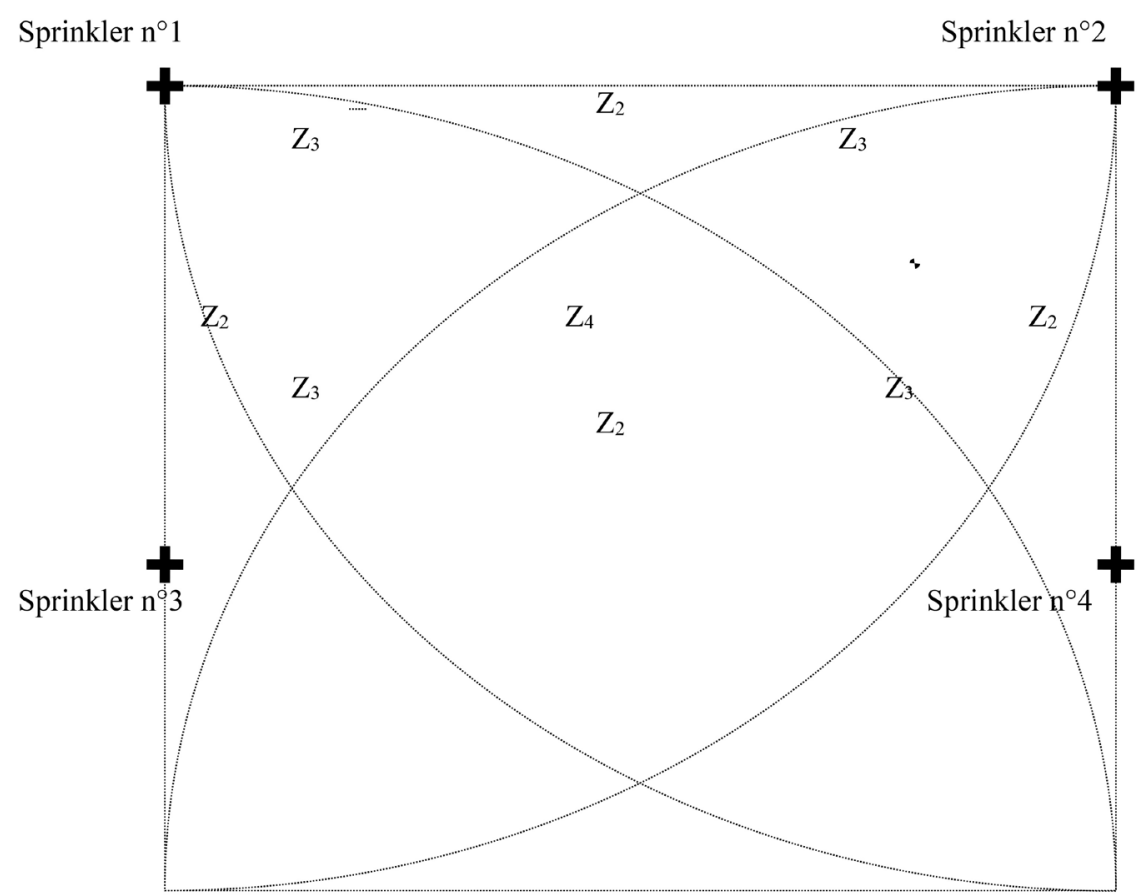

Figure 2. Irrigated zones within a square device of 4 sprinklers with spacing $=$ scope. 
and last lateral, the laterals which are one third and two thirds of the length of the main pipe. On each of these four laterals, the flow rate of the first and last drippers and those located at one third and two thirds of the length of the lateral is measured (Daghara and al. 2020) [8].

The following parameters are often used for the assessment of uniformity for each farm, namely:

- the average of all measured flows: $q_{\text {avg }}=($ sum of 16 values $) / 16$.

- the average of 4 values of the lowest flows: $q_{\min }=$ (sum of the 4 most low) $/ 4$.

- the coefficient of uniformity:

$$
\mathrm{CU}=\left(q_{\text {min }} / q_{\text {moy }}\right) * 100
$$

\subsubsection{Satellite Images and Maps}

Satellite images taken through which this phenomenon was tracked and its prevalence was determined by comparing land cover map of 1988 and 2009 of the study area. The spot image of 2014 was used also.

\section{Results and Discussions}

\subsection{Soil Salinity Spreading}

Salinities were measured in limited areas. While the salinities measured outside the irrigated area were around $1 \mathrm{dS} / \mathrm{m}$; salinities inside irrigated areas reached even $6 \mathrm{dS} / \mathrm{m}$ under squash and tomato in August 2018. Even though these salinities can be considered acceptable for squash, barley and even tomato with some yield reduction, unfortunately any other crop with high added-value, non tolerant to salinity can't be grown.

\subsection{Water Irrigation Salinity}

Measurements were done in February 2018. The transferred water salinity is high (about $4 \mathrm{dS} / \mathrm{m}$ ) but aquifer is of good quality $(1 \mathrm{dS} / \mathrm{m})$, an integrated water resources management is necessary in this area in the aim to better manage irrigation (Dagharib and al., 2020) [9].

\subsection{Irrigation Uniformity Assessment}

1) Case of tomato and squash irrigated with localized irrigation

Five farms were considered ( 2 for squash and 3 for tomato), tomato is the more important crop grown in the region. The discharge values are given in Table 2 and Table 3.

For vegetable crops, the irrigation equipment is newly installed but what is missing is the cleaning of the drippers. Indeed, the plugging is very clear on some drippers and we note the absence of filtration stations. The drippers are of the on-line type with a nominal flow rate of $2 \mathrm{l} / \mathrm{h}$.

2) Case of olive trees irrigated by localized irrigation

Five olive farmers were considered. A strong variability of the flow rates is observed varying between 5.1 and $1.3 \mathrm{l} / \mathrm{h}$ (Table 4); we also note the absence of 
Table 2. Dripper discharges measured within squash and tomato plots (l/h).

\begin{tabular}{cccccccccccccccccccccccccc}
\hline Lateralnumber & \multicolumn{1}{c}{ First dripper discharges (1/h) } & \multicolumn{1}{c}{ Dripper's discharges at $1 / 3(1 / \mathrm{h})$} & Dripper's discharges at $2 / 3$ (1/h) Last dripper's discharges $(\mathrm{l} / \mathrm{h})$ \\
\hline Number of farmers & 1 & 2 & 3 & 4 & 5 & 1 & 2 & 3 & 4 & 5 & 1 & 2 & 3 & 4 & 5 & 1 & 2 & 3 & 4 & 5 \\
First lateral & 2.2 & 2.2 & 2.7 & 1.5 & 2 & 2.1 & 2.2 & 2.2 & 1.4 & 2.2 & 2.1 & 2.3 & 2 & 1.4 & 2.3 & 1.9 & 2.4 & 2.1 & 1.7 & 2 \\
Lateral at 1/3 & 3.0 & 1.9 & 2 & 1.3 & 1.7 & 2.2 & 1.8 & 1.9 & 1.2 & 1.5 & 2 & 1.8 & 1.8 & 1.4 & 1.5 & 1.7 & 2.0 & 1.8 & 1.5 & 1.1 \\
Lateral at 2/3 & 3.5 & 2 & 2 & 1.7 & 1.4 & 2 & 1.7 & 1.7 & 1.3 & 1.3 & 2 & 1.9 & 1.8 & 1.3 & 2 & 1.9 & 1.7 & 1.7 & 1.2 & 1.3 \\
Last lateral & 1.8 & 1.8 & 1.9 & 1.2 & 1.4 & 2 & 1.7 & 1.4 & 1.1 & 1.4 & 1.9 & 1.5 & 1.3 & 1.4 & 1.1 & 1.7 & 1.3 & 1.3 & 1.2 & 1.1 \\
\hline
\end{tabular}

Table 3. Average discharge, uniformity coefficient measured within squash and tomato plots.

\begin{tabular}{cccc}
\hline $\begin{array}{c}\text { Farm's } \\
\text { numbers }\end{array}$ & Average discharge (l/h) & $\begin{array}{c}\text { Average of the fourth } \\
\text { lowest discharges }(1 / \mathrm{h})\end{array}$ & Uniformity coefficient CU (\%) \\
\hline 1 & 2.12 & 1.77 & 83 \\
2 & 1.86 & 1.55 & 83 \\
3 & 1.74 & 1.42 & 82 \\
4 & 1.36 & 1.17 & 86 \\
5 & 1.58 & 1.15 & 73 \\
\hline
\end{tabular}

Table 4. Average dripper disharges measured by olive tree $(1 / \mathrm{h})$.

\begin{tabular}{|c|c|c|c|c|c|c|c|c|c|c|c|c|c|c|c|c|c|c|c|c|}
\hline \multirow{2}{*}{$\begin{array}{c}\text { Lateralnumber } \\
\text { Number of farmers }\end{array}$} & \multicolumn{5}{|c|}{ First dripper discharge $(1 / h)$} & \multicolumn{5}{|c|}{ Dripper's discharge at $1 / 3(1 / \mathrm{h})$} & \multicolumn{5}{|c|}{ Dripper's discharge at $2 / 3(1 / \mathrm{h})$} & \multicolumn{5}{|c|}{ Last dripper's discharge $(1 / \mathrm{h})$} \\
\hline & 1 & 2 & 3 & 4 & 5 & 1 & 2 & 3 & 4 & 5 & 1 & 2 & 3 & 4 & 5 & 1 & 2 & 3 & 4 & 5 \\
\hline First lateral & 5 & 4 & 5.1 & 4 & 5.3 & 4.4 & 4.2 & 4.2 & 4.7 & 4 & 4.7 & 4.6 & 4.3 & 4.2 & 5.0 & 3.9 & 4.3 & 4 & 4 & 4.9 \\
\hline Lateral at $1 / 3$ & 5.1 & 2 & 4.1 & 1.9 & 1.9 & 4.2 & 1.9 & 3.9 & 4.7 & 5 & 3.6 & 2 & 3 & 4.4 & 4.9 & 3.1 & 3.9 & 4.1 & 4.1 & 4.9 \\
\hline Lateral at $2 / 3$ & 4 & 3 & 4 & 1.7 & 1.9 & 4.1 & 1.9 & 3.9 & 3.2 & 2 & 3.9 & 2.7 & 3.3 & 4.1 & 4.1 & 3.1 & 2.9 & 4 & 2 & 4.3 \\
\hline Last lateral & 3.5 & 3.5 & 3.6 & 1.3 & 1.4 & 4.1 & 1.9 & 3.3 & 1.4 & 3 & 3.2 & 2.9 & 3.2 & 2 & 3 & 3.1 & 2.1 & 3 & 2 & 3.0 \\
\hline
\end{tabular}

filtration system or its failure. According to farmers, the nominal flow rate is 4 1/h. There are four drippers by tree.

Uniformity coefficients of $49 \%$ were calculated indicating the very poor use of irrigation water (Table 5). In this case, the drippers are of the on-line type, any lost or blocked dripper is replaced by another emitter, which does not necessarily have the same nominal flow rate as the faulty emitter. This resulted in very poor uniformity of irrigation. They use drippers with a nominal flow of $2 \mathrm{l} / \mathrm{h}$ intended for vegetable crops for irrigation of olive trees and vice versa.

The irrigation durations retained are almost 6 or 8 hours corresponding to the presence of the farmers on the plots and do not obey any hydraulic calculation especially since it is a very light soil where the field capacity and the wilting point vary between $11 \%-2.8 \%$ and $8.2 \%-1.8 \%$ respectively. Not only the irrigation equipment and the network must be reviewed, but the problem of irrigation management is also raised.

3) Case of wheat irrigated by hand-move sprinkler 
Table 5. Average discharge, uniformity coefficient measured within squash and tomato plots.

\begin{tabular}{cccc}
\hline $\begin{array}{c}\text { Farm's } \\
\text { numbers }\end{array}$ & $\begin{array}{c}\text { Average discharge } \\
(\mathrm{l} / \mathrm{h})\end{array}$ & $\begin{array}{c}\text { Average of the fourth } \\
\text { lowest discharges }(\mathrm{l} / \mathrm{h})\end{array}$ & \begin{tabular}{c} 
Uniformiy coefficient CU (\%) \\
\hline 1
\end{tabular} $4^{.0}$ \\
2.0 & 3.2 & 80 \\
3 & 3.8 & 1.9 & 63 \\
4 & 3.2 & 3.2 & 94 \\
5 & 3.5 & 1.7 & 53 \\
\hline
\end{tabular}

To evaluate the sprinkler irrigation, two methods were used (at laboratory and field level):

- Laboratory method

Measured intensities at different distances from the axis of the sprinkler are given in Table 6.

The resulting intensity obtained in the middle of each of 3 zones $Z_{4}, Z_{3}$ and $Z_{2}$ (Figure 2) corresponding to the sum of the intensities coming from different sprinklers which spray the zone according to the spacing of the sprinkler (Table 6) was calculated. Zones $Z_{4}, Z_{3}$ and $Z_{2}$ are irrigated by respectively $4 ; 3$ and 2 sprinklers. The resulting intensities calculated in the middle of zones $Z_{4}, Z_{3}$ and $Z_{2}$ are respectively $8.8 \mathrm{~mm}, 10.2 \mathrm{~mm}$ and $7.6 \mathrm{~mm}$. The theoretical uniformity coefficients calculated by Equation (2) are acceptable, it is about $90 \%$.

- Field method

The field measurements of the rainfall intensities in 9 rain-gauges installed in the different zones $Z_{4}, Z_{3}$ and $Z_{2}$ gave the following respective intensities 5 $\mathrm{mm} / \mathrm{h}, 10 \mathrm{~mm} / \mathrm{h}$ and $4.5 \mathrm{~mm} / \mathrm{h}$ with an overflow of the humidified zone to the outside the square $A_{1}, A_{2}, A_{3}$ and $A_{4}$ on the side of the sprinkler $A_{1}$ under the effect of the wind. Very fine droplets can be easily blown away. In the absence of the wind, the surface watered by a sprinkler is circular. As soon as the wind speed exceeds a certain threshold $(4 \mathrm{~m} / \mathrm{s})$, this surface takes a more or less ovoid shape. The pressure was only $17 \mathrm{~m}$ lower than the nominal pressure $(30 \mathrm{~m})$. Low pressure causes a spreading of the water distribution with the formation of a double ring. A coefficient of uniformity of $64 \%$ was calculated by applying Equation (2).

The uniformity coefficient measured in the field is low compared to that calculated based on laboratory data in the absence of wind. The pressure is different, in addition to the presence of a fairly strong wind. Although the material used meets the standards, a good theoretical coefficient of uniformity of $90 \%$ was obtained in the laboratory, but the uniformity coefficient obtained in the field is only $63 \%$. The management of sprinkler irrigation, the nominal conditions of use of irrigation equipment in this perimeter should be reviewed; the same remark as in the case of localized irrigation. 


\subsection{Evolution of Irrigated Areas, Shrub Vegetationand Bare Soil Surfaces in the Study Area}

There was a significant decrease in the natural vegetation and degradation in most of the land in the study area. About $85 \%$ of the study area was classified as "moderately" or "severely" degraded. This is due to unmanaged agricultural practices and over-grazing. Irrigated area decreases from 18,000 to 12,000 ha between 1996 and 2008. The shrub vegetation decrease is very clear between 1988 and 2009 (from about 40,000 ha to only 26,000 ha), (Figure 3), (Mnsur, 2014) [10].

An increase of bare soil is very clear jumping from 23,000 ha to about 35,000 ha. Sparse vegetation is constant (about 25,000 ha).

By comparing land cover maps of 1988 and 2009, the decrease of shrubs vegetation and irrigated areas is clear also (Figure 4 and Figure 5).

Table 6. Measured intensities at different distances from the axis of the sprinkler.

\begin{tabular}{cc}
\hline Distance from the axis of the sprinkler & Intensities $(\mathrm{mm} / \mathrm{h})$ \\
\hline 1 & 7.5 \\
2 & 7.3 \\
6 & 5.0 \\
8 & 4.1 \\
10 & 2.6 \\
12 & 2.1 \\
16 & 0.05 \\
\hline
\end{tabular}

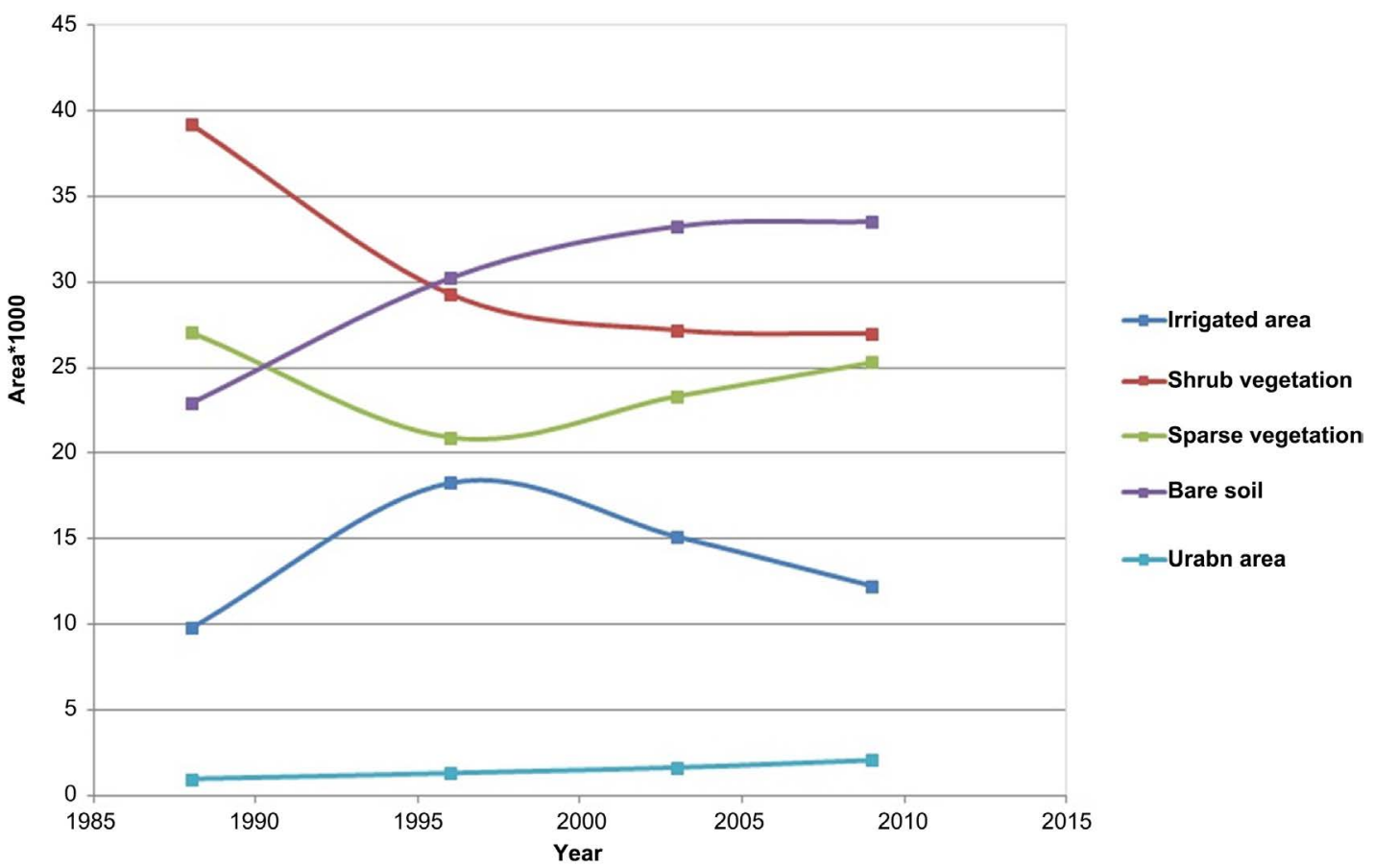

Figure 3. irrigated areas, shrub vegetation, bare soil evolution in Al-Hira area between 1988 and 2008. 


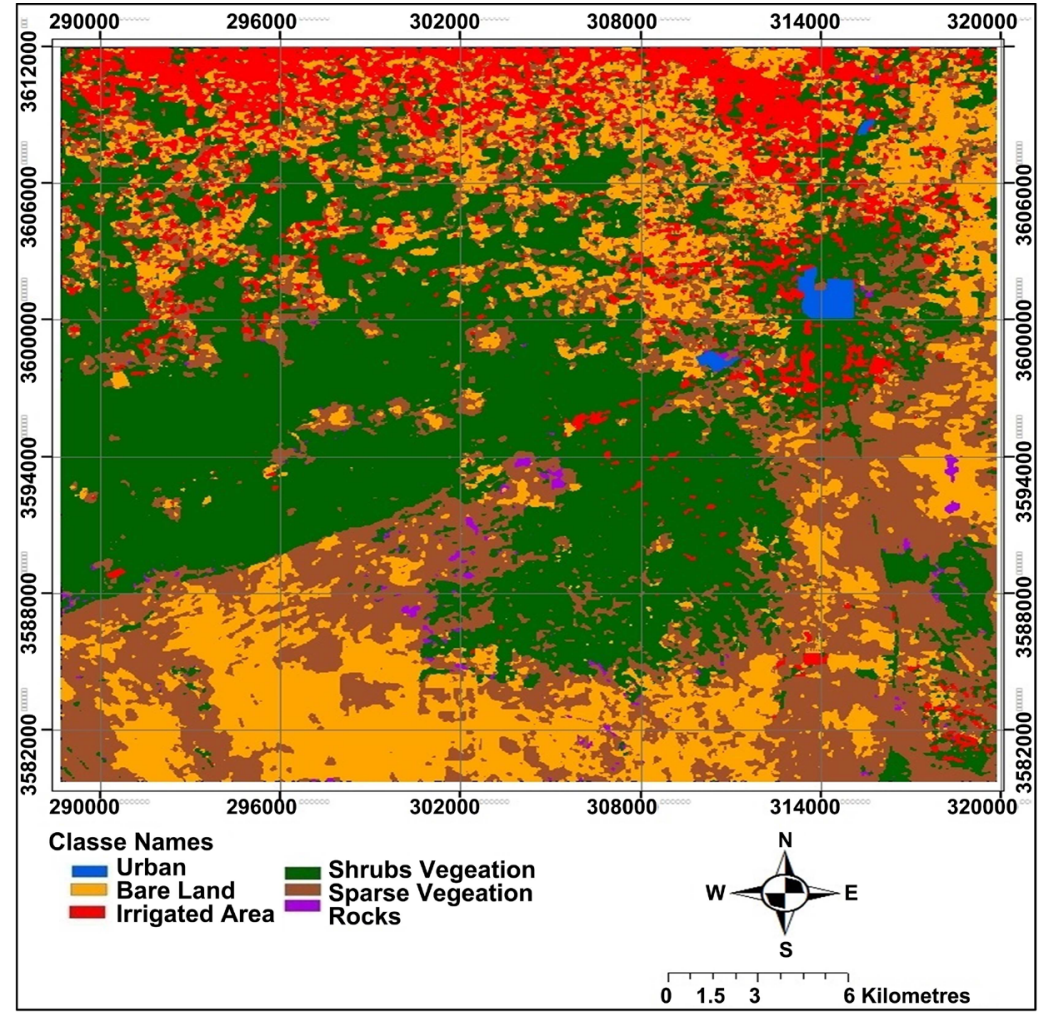

Figure 4. Land cover map of 1988 of the study area.

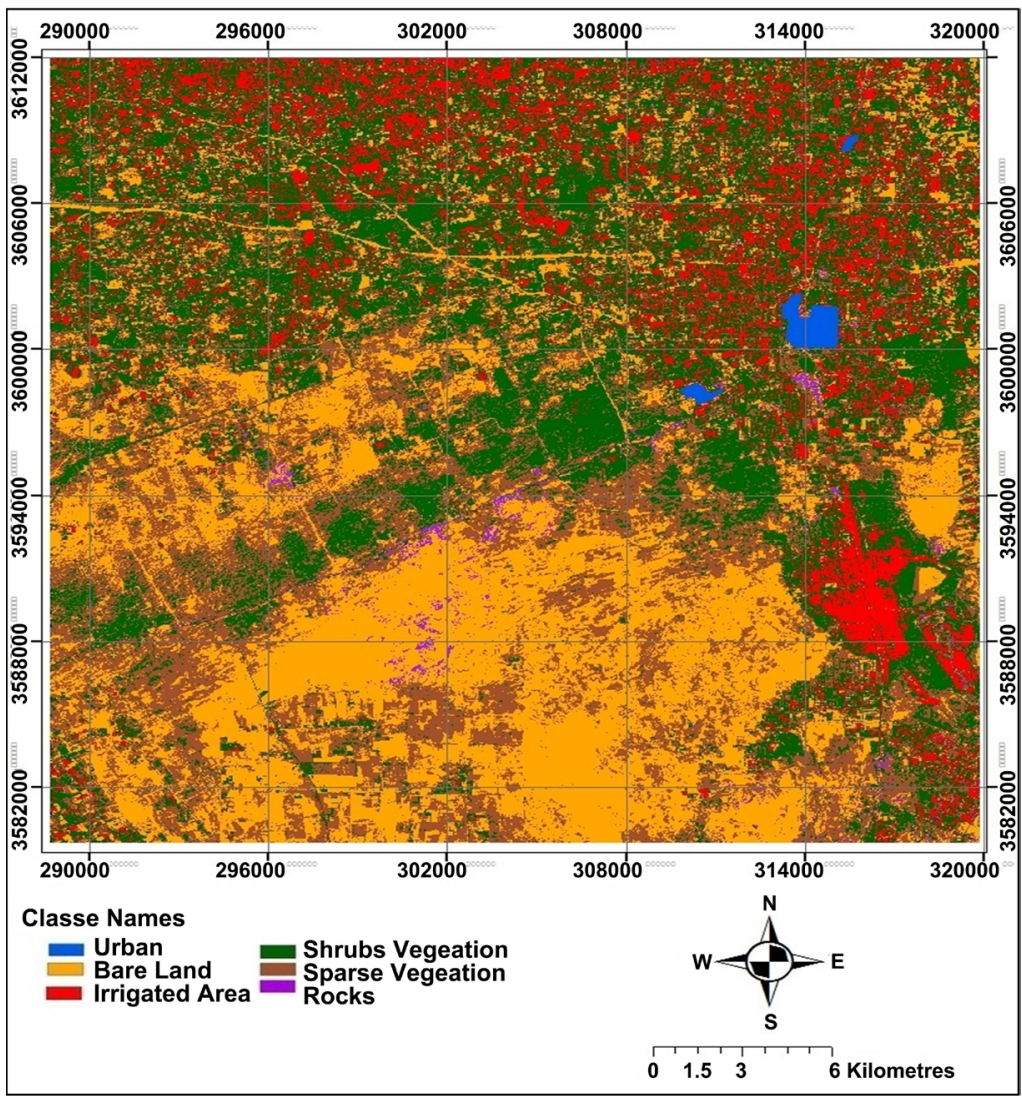

Figure 5. land cover map of 2009 of the study area. 


\subsection{Sand Dunes}

Sand dunes are sandy clusters of different shapes with a length between 13 meters and 460 meters approximately and important heights (Figure 6).

The results of the study area show that there is a significant reduction in the cultivated areas. These areas have changed and turned into non-cultivated areas and pastures. The study showed that there is a noticeable increase in the desertified area as shown in Figure 7.

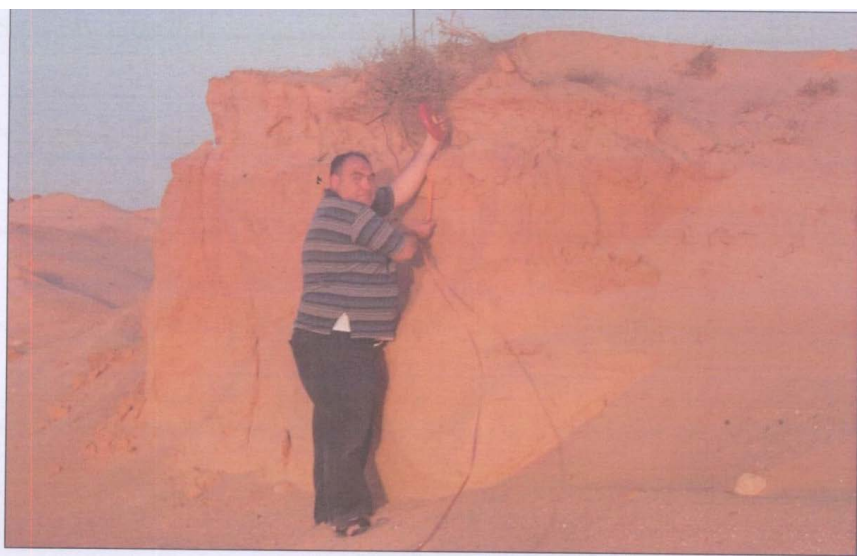

Figure 6. Sand dunes in El Hira study area.

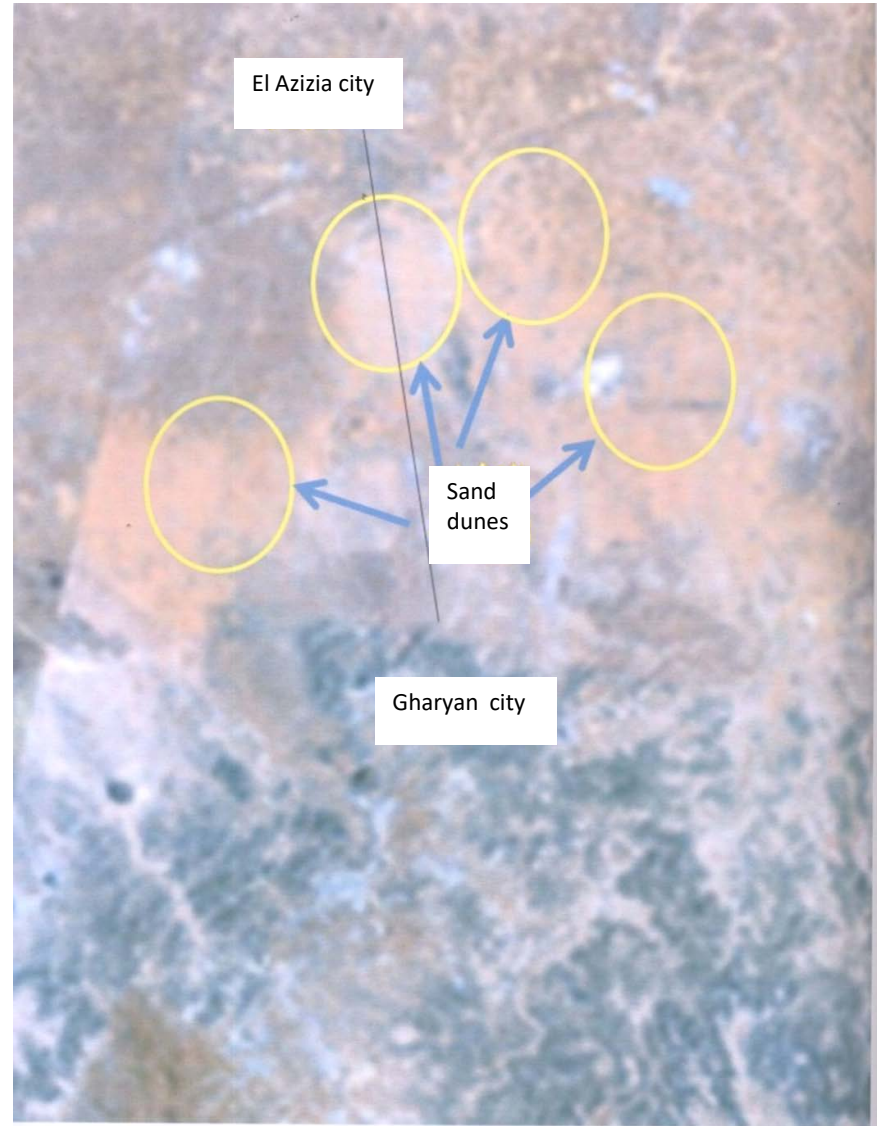

Figure 7. Landsat satellite imagery shows desertification status (2005). 


\section{Conclusions}

Even though this is a very preliminary study carried out under the very difficult conditions that Libya currently passes through, this area is subject to overexploitation of natural resources; bare areas in clear increase, irrigated area in clear decline; shrub vegetation is also decreasing. The irrigation assessment clearly showed 1) very old irrigation network, 2) low uniformity (less than 50\%) and irrigation doses were very high compared to soil retention capacity.

While the irrigation equipment appears to meet the standards, unfortunately the way it is used in the field is very wrong. The uniformity coefficient obtained in the field is only $63 \%$, while a good uniformity coefficient of $83 \%$ is obtained in the laboratory in the case of sprinkler irrigation. For localized irrigation where on-line drippers are used, often $4 \mathrm{l} / \mathrm{h}$ drippers are used in place of $2 \mathrm{l} / \mathrm{h}$ and vice versa. In addition, this soil has a low retention capacity, surely the deep percolations are very important.

The spreading of salinity is clear in this irrigated area, a value of $5 \mathrm{dS} / \mathrm{m}$ is measured inside the irrigated areas while it is only $1 \mathrm{dS} / \mathrm{m}$ outside these irrigated areas.

\section{Acknowledgements}

The authors wish to thank the technicians of the University of Tripoli for their technical assistance.

\section{Conflicts of Interest}

The authors declare no conflicts of interest.

\section{References}

[1] UNEP (1978) Desertification Control, Bulletin $\mathrm{N}^{\circ} 3$.

[2] Ben Mahmoud, K. (1993) Libyan Soil (National Library) Publications of the National Authority for Scientific Research. Benghazi, Libya.

[3] Hamza, S. (2006) Follow-Up of Sand Dune Encroachment Using Remote Sensing and GIS Technology. Academy of Graduate Studies, Tripoli.

[4] El Zarroug, M.R., Daghari, I. and Abou Zakher, A.A. (2020) A Survey of Desertification in Al-Hira and Its Surroundings Areas in Libya. JNS Journal, 74, 4382-4387.

[5] Aragüés, R., Urdanoz, V., Çetin, M., Kirda, C., Daghari, H., Ltifi, W., Lahlou, M. and Douaik, A. (2011) Soil Salinity Related to Physical Soil Characteristics and Irrigation Management in Four Mediterranean Irrigation Districts. Agricultural Water Management, 98, 959-966. https://doi.org/10.1016/j.agwat.2011.01.004

[6] Bani, A., Daghari, I., Hatira, A., Chaabane, A. and Daghari, H. (2020) Sustainable Management of a Cropping System under Salt Stress Conditions (Korba, Cap-Bon, Tunisia). Environmental Science and Pollution Research, 24, 2-9. https://doi.org/10.1007/s11356-020-09767-0

[7] Cemagref (1990) Guide pratique de l'irrigation, France, $319 \mathrm{p}$.

[8] Daghari, I., Bani, A., Bousnina, H. and Chaabane, A. (2020) On-Farm Water and Salt Management under a Strawberry-Pepper Combination in the Korba Area. Irri- 
gation and Drainage, 69, 441-447. https://doi.org/10.1002/ird.2422

[9] Daghari, I., El Zarroug, M.R., Muanda, C. and Shanak, N. (2020) Best Irrigation Scheduling Way with Saline Water and Desalinated Water: Field Experiments. La Houille Blanche, 106, 72-74. https://doi.org/10.1051/lhb/2020037

[10] Mnsur, S. (2014) The Application of Land Degradation Technique in the Jeffara Plain of Libya. Unpublished PhD Thesis, Hallam Sheffield University, Sheffield. 